\title{
Microbiological investigation of wild, cultivated mussels (Mytilus galloprovincialis L. 1819) and stuffed mussels in Sinop-Turkey
}

\section{Demet Kocatepe ${ }^{1}$, Gökay Taşkaya ${ }^{2}$, Hülya Turan², Yalçın Kaya²}

1 - Sinop University, School of Tourism and Hotel Management, Department of Food \& Beverage Management, Sinop, Turkey

2 - Sinop University, Fisheries Faculty, Department of Fish Processing Technology, Sinop, Turkey

\section{Keywords:}

Mussel

Stuffed mussel

E.coli

Coliform.

Public health

Article history:

Received 27.02.2016

Received in revised

form 25.04.2016

Accepted 30.06.2016

Corresponding author:

Demet Kocatepe E-mail: demetkocatepe@ hotmail.com

\section{Abstract}

Introduction. To purpose of study - to investigate the microbiological properties of wild and cultivated mussels and stuffed mussels sold by restaurants and street vendor in August and September.

Materials and methods. In total 68 mussel (Mytilus galloprovincialis L. 1819) and stuffed mussel samples were investigated by using total aerobic mesophilic bacteria, total Coliform bacteria, Escherichia coli and Vibrio spp. were performed by standard procedures. The sampling was carried out aseptically for the microbiological analysis. All of the microbiological analyses were conducted in triplicate.

Results and discussion. The initial total aerobic mesophilic bacteria, total Coliform bacteria, E. coli counts of wild and cultivated mussels in August were 4.04 Log CFU/g and 3.55 Log CFU/g, 3.69 Log CFU/g and 3.09 Log CFU/g, $0.59 \mathrm{Log} \mathrm{CFU} / \mathrm{g}$ and $0.39 \mathrm{Log} \mathrm{CFU} / \mathrm{g}$ respectively. Total bacteria, total coliform and Vibrio spp. numbers of wild mussels were higher than cultivated mussels $(\mathrm{p}<0.05)$. Vibrio spp. were not found associated with cultivated mussels.

The number of total aerobic mesophilic bacteria, total Coliform bacteria and E. coli in stuffed mussels sold by street vendors were determined higher than that found associated with stuffed mussels sold in restaurant $(p<0.05)$ in August. In September, E. coli were not detected in stuffed mussels sold by restaurants, and street vendor. No stuffed mussel samples exceeded an acceptable limit value (6 Log CFU/g) for aerobic plate count in the months of August and September. In stuffed mussels Vibrio spp. were found except for stuffed mussels sold by street vendor in September.

The stuffed mussels were made from wild mussels and the aerobic mesophilic bacteria, total Coliform bacteria and E.coli numbers of them were more than wild mussel.

Conclusion. E. coli were not found in stuffed mussels sold in restaurant in both two months, whereas Vibrio spp. were detected in twenty seven of total forty eight stuffed mussel samples collected from street vendors and restaurant. 


\section{Introduction}

The Mediterranean mussel, Mytilus galloprovincialis (Lamarck), is a bivalve and it occurs naturally in Black Sea coast and the other coast of Turkey. In 2012, 2093.4 tons of M. galloprovincialis were caught in Turkey and around $92 \%$ of it was in Western Black Sea region [1]. Especially in Sinop region, collecting and consumption of wild mussel are developed. Mussel's edible portion contains approximately $80 \%$ water, $9-13 \%$ protein, 0 $2 \%$ fat and $1-7 \%$ glycogen depending on the season, feeding, maturity and water temperature [2]. Moreover, Mediterranean mussel (M. galloprovincialis) harvested from the Black Sea coast contains about $82.99-86.06 \%$ moisture, $10.24-10.30 \%$ protein, 1.49 $1.14 \%$ fat and $1.14-0.95 \%$ ash $[3,4]$.

M. galloprovincialis present along the national coast and consumer appreciate it because of its organoleptic properties; it is retained also after processing, and for the competitive price if compared with other bivalves [5]. In our country, the mussels are generally exported. In addition, they are widely consumed as fried in some restaurants. In addition, some of them are canned or frozen [6].

Street food is defined as "ready-to-eat foods and beverages prepared and/or sold by street vendors and hawkers, especially in the street or other similar public places" by FAO [7]. The most popular local street foods in Turkey are meat and chicken doner, bagel, stuffed mussel, fried mussel, ice cream, fish bread, raw meatballs. Stuffed mussel is a delicious traditional food like an appetizer especially in coastal areas in Turkey. Generally, street vendors sell stuffed mussel so that it is called as a street food. Stuffed mussels along the Sinop coast are generally sold in August and September by street vendors and restaurants.

Kışla and Üzgün [8] defined stuffed mussel produced in Turkey as "mussel shells are cleaned with water by scraping with a knife, and any beards are removed; mixture is prepared with rice, vegetable oil, salt, and spices; mixture is stuffed into each shell included mussel flesh, and shells are closed tightly before cooking by steaming; vegetable oil is sprayed on the shells of stuffed mussels because of bright surface".

The microbial load of seafood after collecting is closely related to environmental conditions such as; water temperature, salt content, distance between localization of collected and polluted areas (human and animal feces), natural occurrence of bacteria in water, methods of harvest, handling, storage practices and chilling factors $[9,10]$.

Most food vendors ignore of good food handling practices, exposing foods to dangerous conditions such as unsuitable conditions, unsafe storage and poor timetemperature conditions, so that it can cause food poisoning. In Selangor-Malaysia in 1993, two cholera outbreaks were linked to street food [11, 12]. Ready-to-eat foods such as stuffed mussels sold in the open areas without any precautions could be a major cause of food-poisoning and foodborne diseases [13].

The purpose of this study was to examine; a) the microbiological quality differences of wild and culture Mediterranean mussel (M. galloprovincialis) collected from Sinop region, and b) the microbiological qualities of stuffed mussel sold by street vendors and restaurants in Sinop.

\section{Materials and methods}

Materials. Mediterranean mussels ( $\mathrm{n}=20 ; 10$ wild, 10 cultivated) (Figure 1) were collected from Black Sea and transported within half an hour to the laboratory on August. 
Cultured mussels were collected in submerged long line mussel culture system in offshore in Black Sea.

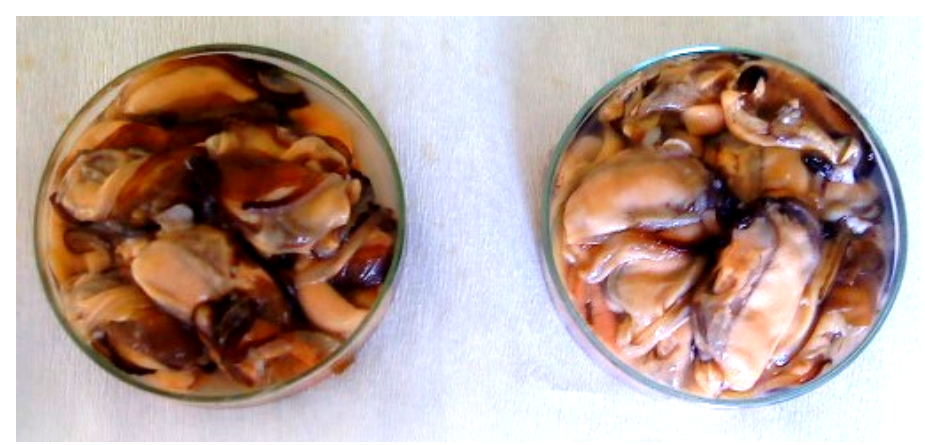

Fig 1. Wild (left) and cultivated (right) mussels (Photos: D. Kocatepe)

Stuffed mussels ( $\mathrm{n}=48$ ) were sold in the afternoon (roughly 5:00 p.m.) from street vendors and restaurants in August and September. The stuffed mussels investigated in this study were produced from wild mussels. Products were prepared in the morning and they were put up for sale throughout the day on the bench by street vendors but they are kept at cold and offered for sale at bench gradually at the restaurant.

Methods. In the sampling days, the mean of weather temperature in August and September were $28^{\circ} \mathrm{C}$ and $24^{\circ} \mathrm{C}$, respectively.

The sampling was carried out aseptically for the microbiological analysis. Each mussel meat and stuffing mixture was removed from the shells, mixed, and a 10-g portion transferred into $90 \mathrm{ml}$ of sterile $0.1 \%$ peptone water containing $3 \% \mathrm{NaCl}$ except from Vibrio spp. analysis. The sample was homogenized for $2 \mathrm{~min}$ and serially diluted as needed for plating. The following media and incubation condition were used. Total mesophilic aerobic bacteria (TMAB) were determining using Plate count agar (PCA, Merck code: 105463.0500) after incubation for 2 day at $30^{\circ} \mathrm{C}$. Total coliform bacteria (TCB) were enumerated on violet red bile agar (Merck 1.15525, Lancashire, UK) by the double-layer pour plate method and incubated at $35^{\circ} \mathrm{C}$ for $24 \mathrm{~h}$ [14]. For E. coli bacteria used violet red bile+Mug agar (Merck 1.4030, Lancashire, UK) and incubated at $37^{\circ} \mathrm{C}$ for $18 \mathrm{~h}$. Colonies with blue fluorescence under UV light were counted [15].

To determine Vibrio spp.; 25 grams of homogenized sample mixture were transferred into sterile bottles. Then $225 \mathrm{ml}$ of alkali-peptone water (Merck 1.01800, Lancashire, UK) was added and incubated at $35-37{ }^{\circ} \mathrm{C}$ for $8 \mathrm{~h}$. Then a loop full enrichment broth was streak plated onto thiosulfate-citrate-bile salt sucrose agar (Merck 1.10263, Lancashire, UK) and plates incubated at the same temperature for $24 \mathrm{~h}[15,16]$. After incubation, gram-stained and tested for oxidase activity and ability to ferment glucose (using modified Hugh Leifson's medium including $26 \mathrm{~g} \mathrm{NaCl} \mathrm{g/L} \mathrm{[8].} \mathrm{The} \mathrm{results} \mathrm{were} \mathrm{given} \mathrm{as} \mathrm{the} \mathrm{number} \mathrm{of}$ positive samples.

All of the microbiological analyses were conducted in triplicate. Microbiological data were transformed into logarithms of the number of colony-forming units ( $\left.\mathrm{CFU} \mathrm{g}{ }^{-1}\right)$.

Microsoft Excel (Microsoft Corp., Redmond, WA) and Minitab Release 13.20 (Minitab, Inc., State College, PA) evaluated statistical analysis. One-way variance analysis used for statistical evaluation of data [18]. 


\section{Results and discussion}

The results of microbial analysis of wild and cultivated mussels at Black Sea are shown in Table 1. Mussels pump large quantities of water through their bodies, so they accumulate the toxic substances and microorganisms present in ambient water [19].

Table 1

The microbial flora of wild mussels and cultivated mussels in Sinop, south of Black sea

\begin{tabular}{|c|c|c|c|c|c|}
\hline 总 & Product & $\begin{array}{c}\text { TMAB } \\
\left(\log ^{-1}\right) \\
\left.\text { CFUg }^{-1}\right)\end{array}$ & $\begin{array}{c}\text { TCB } \\
\left({\log C F U g^{-1}}^{2}\right)\end{array}$ & $\begin{array}{c}E . \text { coli } \\
\left(\log C F \operatorname{Cg}^{-1}\right)\end{array}$ & $\begin{array}{l}\text { Vibrio } \\
\text { spp.* }\end{array}$ \\
\hline \multirow{2}{*}{ 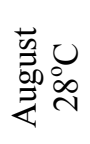 } & Wild mussels & $4.04 \pm 0.03^{\mathrm{a}}$ & $3.69 \pm 0.02^{\mathrm{a}}$ & $0.59 \pm 0.24^{\mathrm{a}}$ & $10(10)^{\mathrm{a}}$ \\
\hline & Cultivated mussels & $3.55 \pm 0.02^{\mathrm{b}}$ & $3.09 \pm 0.02^{\mathrm{b}}$ & $0.39 \pm 0.21^{\mathrm{a}}$ & $-(10)^{b}$ \\
\hline
\end{tabular}

Note:

TMAB: Total aerobic mesophilic bacteria. TCB: Total Coliform bacteria.

* Values in parentheses are number of samples; values outside of parentheses are number of positive samples.

a, b, c $(\downarrow)$ : Means in the same column with the same letter do not differ at the level of 0.05 significance.

“_" Not detected.

The initial TMAB counts of wild and cultivated mussels in August were 4.04 Log CFU/g and 3.55 Log CFU/g, respectively (Table 1). TMAB and TCB numbers of cultivated mussels were lower than wild mussel $(\mathrm{p}<0.05)$. While the Vibrio spp. was detected in $100 \%$ of wild mussels, Vibrio spp. were not found in none of cultivated mussel samples. The differences between wild and cultivated mussels were statistically significant $(p<0.05)$. Çağlak et al. [18] and Ulusoy [20] reported that the number of total viable bacteria of mussels (M. galloprovincialis) on day harvesting were $3.25 \mathrm{Log} \mathrm{CFU} / \mathrm{g}, 2.34 \mathrm{Log} \mathrm{CFU} / \mathrm{g}$, respectively. The total bacteria, Coliform and $V$. parahaemolyticus counts of mussels collected from three different stations on the coast of Trabzon in Black Sea during a year were maximum 5.62, 4.77, 3.47 Log CFU/g, respectively [21]. According to the results, cultivated mussels contained less microorganisms than wild mussels. The microbiological properties of water may affect the microbial flora of mussels. Microbiological load of wild mussels caught in coast of Sinop is higher than mussels harvested from the cultivating system in the open sea area, because of sewage, shipyards and garbage.

The microbiological results of stuffed mussels were sold by street vendors and restaurant in Sinop coast of Turkey are shown in Table 2. 
The microbial flora of stuffed mussels sold by street vendors and restaurant

\begin{tabular}{|c|c|c|c|c|c|}
\hline 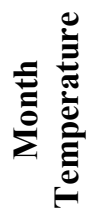 & Product & $\begin{array}{c}\text { TMAB } \\
\left(\log \text { CFUg }^{-1}\right)\end{array}$ & $\begin{array}{c}\text { TCB } \\
\left(\log \text { CFUg }^{-1}\right)\end{array}$ & $\begin{array}{c}\text { E. coli } \\
\left(\log \text { CFUg }^{-1}\right)\end{array}$ & $\begin{array}{l}\text { Vibrio } \\
\text { spp.* }\end{array}$ \\
\hline \multirow{2}{*}{ 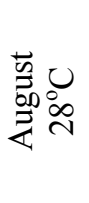 } & $\begin{array}{l}\text { Stuffed mussels sold } \\
\text { by street vendor }\end{array}$ & $5.35 \pm 0.07^{\mathrm{a}}$ & $4.14 \pm 0.01^{\mathrm{a}}$ & $1.17 \pm 0.39^{\mathrm{a}}$ & $13(16)^{\mathrm{a}}$ \\
\hline & $\begin{array}{l}\text { Stuffed mussels sold } \\
\text { by restaurant }\end{array}$ & $5.02 \pm 0.02^{\mathrm{bA}}$ & $3.31 \pm 0.02^{\mathrm{bA}}$ & $-\quad b A$ & $8(16)^{\mathrm{aA}}$ \\
\hline \multirow{2}{*}{ 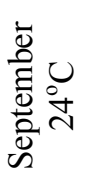 } & $\begin{array}{l}\text { Stuffed mussels sold } \\
\text { by street vendor }\end{array}$ & 1 & 1 & I & I \\
\hline & $\begin{array}{l}\text { Stuffed mussels sold } \\
\text { by restaurant }\end{array}$ & $4.96 \pm 0.01^{\mathrm{A}}$ & $3.08 \pm 0.01^{\mathrm{B}}$ & $-{ }^{\mathrm{A}}$ & $6(16)^{A}$ \\
\hline
\end{tabular}

TMAB: Total aerobic mesophilic bacteria. TCB: Total Coliform bacteria.

"/": Sample was not found.

*Values in parentheses are number of samples; values outside of parentheses are number of positive samples.

$a, b, c(\downarrow)$ : For the two groups, means in the same column with the same letter do not differ significantly at the level of 0.05 significance on August

A, B ( $\downarrow$ ): For the stuffed mussels sold by restaurant, means in the same column with the same letter do not differ significantly at the level of 0.05 significance on August and September.

“_“ Not detected

Stuffed mussels are prepared from wild mussels collected from the coastal areas and then sold from different sale points like restaurants, street vendors, and cafes. No stuffed mussel samples exceeded an acceptable limit value (6 Log $\mathrm{CFU} / \mathrm{g}$ ) for aerobic plate count indicated by TGK [22]. In this study; the numbers of TMAB, TCB and E. coli in stuffed mussels sold in street vendors were higher than stuffed mussels sold by restaurants $(\mathrm{p}<0.05)$ in August. Kök et al. [19] reported that the microbiological analysis of stuffed mussel samples showed that the TMAB were ranging between $<2$ and $6.44 \log \mathrm{CFU} / \mathrm{g}$ in Aydin and İzmir, Turkey.

Maximum acceptable E. coli number for prepared foods (like snacks) and meat products (cooked) is $<10 \mathrm{CFU} / \mathrm{g}$ [23]. Stuffed mussels were sold by street vendor in August exceeded this limit value. Whereas, E. coli were not detected in stuffed mussels sold by restaurant during August and September. Ateş et al. [13] emphasized in their study that $76.6 \%$ samples of stuffed mussel were unacceptable.

Comparing the samples collected from restaurant (it was kept at cold and offered for sale at bench gradually) and street vendors; the stuffed mussels sold in restaurant had lower bacteria than the other had. Hampikyan et al. [24] reported that the total viable bacteria, 
Coliform and E. coli counts of stuffed mussels sold in Istanbul were maximum $2.3 \times 10^{7}$, $5.8 \times 10^{6}, 4.0 \times 10^{1} \mathrm{CFU} / \mathrm{g}$, respectively. According to the studies, the number of bacteria detected from stuffed mussels in Sinop was lower than that sold in Istanbul. There was no differences ( $p>0.05)$ in point of positive sample numbers of Vibrio spp. between the stuffed mussels sold in street and restaurant in August. In September, there could not be found sample from street vendors. TMAB, E. coli, Vibrio spp. in the stuffed mussel sold in restaurant in August and September were similar ( $\mathrm{p}>0.05)$, meanwhile; number of TCB in September significantly decreased $(\mathrm{p}<0.05)$. This may be because of weather temperature.

Total number of bacteria in mussels can be consumed, it should not have been out of 5 billion/g [25]. The total number of mesophyll bacteria of the wild mussels, cultivated mussels and stuffed mussels in Sinop did not exceed consumable limit. Whereas Vibrio spp. were determined in stuffed mussels, therefore the importance of hygiene during processing and initial microbial load of raw mussels must be emphasized. The similarly as our results, Kök et al. [19] indicated that stuffed mussels might constitute a potential health hazard, especially when kept at high ambient temperatures, depending on contamination level and lack of sanitary practices, and therefore, handling practices should require more attention and improvement.

\section{Conclusion}

Mussels filter the water for feeding, therefore; they also take the unwanted substance (industrial waste, petrol compounds, heavy metals, agricultural waste, sewage, pathogenic microorganisms) from the area. Microbial loads of wild mussels show an alteration in cultivated mussels. In our study; microbiological loads of wild mussels obtained from the coast of Sinop and cultivated mussels were compared. Microbiological loads of cultivated mussels were found lower than wild mussels. Consuming of raw mussels collected from sea and stuffed mussels prepared from wild mussels may be dangerous for public health because of especially Vibrio spp. number. It can be said that using of cultivated mussels for stuffing is more appropriate than wild mussel. However, we can safely consume or use the mussels collected from the clean sea/water in terms of microbiological.

\section{References}

1. Tuik (2013), available at:

http://rapor.tuik.gov.tr/reports/rwservlet?hayvancilik=\&report=BALRAPOR3.RDF\&p_yil1 $=2012 \&$ p_madl $=898 \&$ p_kod=1\&desformat $=$ pdf\&p_dil=1\&ENVID=hayvancilikkurumsalE nv.

2. Schormüller J. (1968), Handbuch der Lebensmittel Chemie. Band III 12 Teil Tierische Lebensmittel Eier, Fleisch, Buttermilsch, Springer-Verlag, Heidelberg, Berlin. pp. 15611584.

3. Karayücel S., Kaya Y, Karayücel İ. (2003), Effect of environmental factors on biochemical composition and condition index in the Mediterranean mussel (Mytilus gallaprovincialis Lamarck, 1819) in the Sinop region, Turkish Veterinary Animal Science, 27, pp. 13911396.

4. Turan H., Sönmez G., Çelik M.Y., Yalçın M., Kaya Y. (2008), The effects of hot smoking on the shelf life of Mediterranean Mussel (Mytilus galloprovincialis L.1819) under chilled storage, Journal of Food Processing and Preservation, 32(6), pp. 912-922.

5. Orban E., Di Lena G., Nevigato T., Casini I., Marzetti A., Caproni R. (2002), Seasonal changes in meat content, condition index and chemical composition of mussels (Mytilus galloprovincialis) cultured in two different Italian sites, Food Chemistry, 77, pp. 57-65. 
6. Turan H., Sönmez G., Çelik Y., Yalçın M., Kaya Y. (2007), Effects of different salting process on the storage quality of Mediterranean mussel (Mytilus galloprovincialis L. 1819), Journal of Muscle Foods, 18, pp. 380-390.

7. FAO (1997a), Street foods. FAO food and nutrition paper 63. Report of an FAO technical meeting on street foods, Calcutta, India, 6 to 9 November 1995. Food and Agriculture Organization of the United Nations, Rome.

8. Kışla D., Üzgün Y. (2008), Microbiological evaluation of stuffed mussels (Research Note), Journal of Food Protection, 71(3), pp. 616-620.

9. Feldhusen F. (2000), The role of seafood in bacterial food borne diseases, Microbes and Infection, 2, pp. 1651-1660.

10. Hanashiro A., Morita M., Matté G.R., Matté M.H., Torres E.A.F.S. (2005), Microbiological quality of selected street foods from a restricted area of São Paulo city, Brazil. Food Control, 16(5), pp. 439-444.

11. FAO (1997), FAO maps out future activities in nutrition, hygiene. Street food: small entrepreneurs, big business. Street Foods: FAO Food and Nutrition Paper 63, Food and Agriculture Organization of the United Nations, Rome.

12. Ekanem E.O. (1998), The street food trade in Africa: Safety and socio-environmental issues. Food Control, 9(14), pp. 211-215.

13. Ateş M., Özkızılcık A., Tabakoğlu C. (2011), Microbiological analysis of stuffed mussels sold in the streets, Indian J. Microbiol,51(3), pp. 350-354.

14. Bal'a A.M.F., Podolak R., Marshall D.L. (2000), Microbial and color quality of fillets obtained from steam-pasteurized beheaded and eviscerated whole catfish, Food Microbiology 17, pp. 625-631.

15. Anonymous (2005), Merck Food Microbiology, Ed: AK Halkman. Başak Mat. Ltd. Şti. Ankara, pp. 211.

16. Buck J.D. (1998), potentially pathogenic Vibrio spp. in market seafood and natural habitats from southern New England and Florida, Journal of Aquatic Food Product Technology, 7, pp. 53-61.

17. Sümbüloğlu K., Sümbüloğu V. (2007), Biyoistatistik, Hatipoğlu Yayınları, p.299.

18. Çağlak E., Çaklı S., Kılınç B. (2008), Microbiological, chemical and sensory assessment of mussels (Mytilus galloprovincialis) stored under modified atmosphere packaging, European Food Research and Technology, 226, pp. 1293-1299.

19. Kök F., Şahiner C., Koçak P., Göksoy E.Ö., Beyaz D., Büyükyörük S. (2015), Determination of microbiological quality of stuffed mussels sold in Aydin and İzmir, MANAS Journal of Engineering, 3(1), pp. 70-76.

20. Ulusoy Ş. (2008), Midye Dolmaların Modifiye Atmosferle Paketlenmesi (Yüksek Lisans Tezi), İstanbul Ünv. Su Ürünleri Avlama ve İşleme Teknolojisi Anabilim Dalı, pp. 72.

21. Karaçam H., Boran M., Köse S. (1997), Bacterial contamination of mussels (Mytilus galloprovincialis) in Trabzon coast, Mediterranean Fisheries Congress, Izmir-Turkey, pp. 377-382.

22. TGK (1995), Su Ürünleri Yönetmeliği, Yetki kanunu: 1380, Resmi Gazete: 10.03.1995, no.22223, Ankara

23. TGK (2009), Türk gıda kodeksi mikrobiyolojik kriterler tebliği (Tebli no: 2009/6). Resmi gazette: 06.02.2009. no. 27133, Ankara.

24. Hampikyan H., Ulusoy B., Bingöl E.B., Colak H., Akhan M. (2008), Determination of microbiological quality of some grilled food, salad and appetizers, Turkish Microbiological Society, 38(2), pp. 87-94.

25. Wher M.H. (1978), Attitudes and policies of state governments, Food Technology, 1, pp. 63-67. 